Page 510-519 ISBN: 978-602-6 988-75-1

Web Jurnal Online: jurnal.unmuhjember.ac.id

By: Irfan Nursetiawan; Kiki Endah, Ii Sujai

Digitalization Of Superior Products Sukamaju Village Cihaurbeuti Sub-District Ciamis

District Based On Qr Code And Facebook Marketplace

\title{
DIGITALIZATION OF SUPERIOR PRODUCTS SUKAMAJU VILLAGE CIHAURBEUTI SUB-DISTRICT CIAMIS DISTRICT BASED ON QR CODE AND FACEBOOK MARKETPLACE
}

\author{
Irfan Nursetiawan, Kiki Endah, Ii Sujai \\ Universitas Galuh \\ e-mail: irfan.nursetiawan@gmail.com
}

\begin{abstract}
The purpose of this service activity is to foster an entrepreneurial spirit for rural people who are poorer as partners through the formation of business groups, as well as empowering potential partners in increasing family income through increasing information technology-based creative economic ventures. While the specific target of this service activity, namely in the development of the local economy and the region, is by establishing business groups that can be economically independent and can increase family income in particular and can increase the income of the local economy and the region in general. This activity will be held for 6 (six) months, where there are several stages of activities in the implementation of Community Service (PKM), including (1) initial evaluation; (2) establishment of business groups; (3) training in making QR-Code; (4) training in making Facebook Marketplace; (5) business management assistance; (6) final evaluation, and; (7) special sustainability monitoring. The activity has been carried out, and the village community has begun to use Facebook Marketplace as a media for promotion and product marketing, and the BUMDes have realized the benefits of QRCode as a form of digital-based product identity.
\end{abstract}

Keywords: Featured Village Products, Villages, QR Code, and Facebook Marketplace. 


\section{INTRODUCTION}

The village is currently inseparable from the most important development programs by the central government and local governments. There are so many problems in rural areas that must be the concern of all parties and stakeholders. The several problems that arise, including poverty, inequality, socio-political problems, ideology, and even frequent conflicts over land (agrarian). The welfare of the village community is an expectation and aspiration that the central government and regional government want to realize, in order to create a civilized village community. One solution that can create a prosperous village community, namely through community empowerment. This is in accordance with Law Number 6 of 2014 concerning Villages, stating that Village Community Empowerment is an effort to develop community independence and welfare by increasing knowledge, attitudes, skills, behaviors, abilities, awareness, and utilizing resources through policy setting, programs, activities, assistance, which are in accordance with the essence of the problem and priority needs of the village community.Based on this, empowerment is one way and effort in improving the welfare of rural communities. Similarly, in Sukamaju Village, Cihaurbeuti Subdistrict, Ciamis Regency has a lot of natural resource potential, but it has not been managed optimally. The population in Sukamaju Village is 4,484 in 2017 with ages 0 to 70 years and above. The level of education in Sukamaju Village is dominated by 2,402 elementary school graduates and 640 junior high school graduates. Then for 354 high school graduates, 31 graduates from $\mathrm{S} 1$, and only 1 graduate from S2. Whereas for the livelihoods of the residents of Sukamaju Village it is dominated by 770 farmers and 723 farmers. Then followed by workers as many as 518 people, entrepreneur 315 people, and farm workers 311 people. Overall there are several rural communities belonging to underprivileged people.

The welfare of rural communities is the foundation of achieving a sustainable government development program. The exploration of potential resources in rural areas is one of the hopes for achieving prosperity. Social inequality and poverty are inseparable from rural communities who actually have the potential to progress, and develop.Viewed from the aspect of Natural Resources, Sukamaju Village has a village cash area of 10.2 ha, 5 ha of bamboo forest, 90 ha of land, 140 ha of paddy fields, 30 ha of community plantation land, 12 ha of agricultural land, and 85 community forests Ha. With the potential of these natural resources which are dominated by agricultural land and plantations, there are superior village products from Sukamaju Village, including coffee, ant sugar, and handicrafts that are still characterized by local village location wisdom. But there are the most fundamental problems in the development and marketing of these superior products. The most fundamental problems in business development are lack of access to capital, market, and technology sources, and organizations that are still weak, so that the development of regional superior products is always not smooth in its implementation. Similarly, what happened to the superior products of Sukamaju Village were several obstacles, including: (1) limited production activities; (2) limited product marketing; (3) packaging that is still conventional; (4) equipment is not sufficient for product production and distribution activities; (5) superior product marketing that still does not utilize information technology and (6) lack of Human Resources (HR) in 
production and distribution activities. Obstacles and problems that exist in community empowerment, one of which is in the development of superior village products, the right strategies and solutions are needed. The right solution in dealing with these problems, namely by applying and utilizing technology as an effort in improving the marketing of superior village products. The use of technology is an adaptive form to be able to compete with other competitors and is a synergy between the progress of the age and market needs. Moreover, the development of social media has changed the behavior and lifestyle of a person, and raises a new group of people in cyberspace, namely the internet community or better known as netizens Opportunities and challenges in today's modern era, must change rural communities to be adaptive to the times. The industrial era 4.0 requires that civil society can use technology. Technology that can be applied to assist in marketing superior village products, namely by utilizing (1) QR Code; and (2) Facebook Marketplace. QR Code has many advantages, one of which is the QR Code capable of storing all types of data, such as numeric or numeric data, alphanumeric, binary, kanji or kana. In addition, the QR Code has a smaller display than the barcode. This is because the QR Code is able to hold data horizontally and vertically, so automatically the size of the display QR Code image can only be one tenth of the size of a barcode. Not only that, the QR Code is also resistant to damage, because the QR Code is able to correct errors up to $30 \%$ depending on the size or version. Therefore, although some QR Code symbols are dirty or damaged, data can still be stored and read (Novan, A.M., et al, 2016). The use of social media is also a great way to market a product. This is in line with Chi's opinion (in Holly P., 2013), stating that ...social media defines marketing as a connection between brands and consumers. This means that using social media as a means of promotion can bring together products with consumers or prospective buyers. Thus, the use of social media can help sellers to promote and sell their products to consumers easily. From the statement above it can be concluded, that in an effort to improve the marketing of superior village products a mature marketing strategy is needed and in accordance with market needs. The application of information technology is one of the hopes to increase the amount of sales from superior village products. In addition, assistance in developing the village's superior products is needed to become a catalyst in the process of developing quality superior village products.

\section{LITERATURE REVIEW}

a. Village Community Empowerment

Community empowerment is a development process where people take the initiative to begin the process of social activities and are steps to improve the situation and condition of themselves. In this service focused on empowering rural communities. According to Government Regulation Number 43 of 2014 concerning the Implementation Regulation of Law Number 6 of 2014 concerning Villages in article 127 paragraph (2) Village Community Empowerment is carried out, by:

a. encourage community participation in village planning and development carried out in a self-managed manner by the village; 
b. develop sustainable village development programs and activities by utilizing human resources and natural resources in the village;

c. develop village development planning in accordance with the priorities, potential and value of local wisdom;

d. compile planning and budgeting in favor of the interests of the poor, people with disabilities, female children, and marginalized groups;

e. develop a system of transparency and accountability in the implementation of Village Government and Village development;

f. utilizing village community organizations and traditional institutions;

g. encouraging community participation in village policy formulation carried out through village meetings;

h. organizes improvements in the quality and capacity of human resources in the village community;

i. carry out sustainable village community assistance; and

j. conduct monitoring and monitoring of the implementation of the Village Government and Village development carried out in a participatory manner by the village community.

Based on this, community empowerment, especially in rural areas, relies on utilizing or utilizing available resources, namely Human Resources (HR) and Natural Resources (SDA) available. The maximum utilization of the Village's potential will arouse and accelerate development in rural areas. Besides that the potential of the Village is part of the potential of the local economy. According to Prasetyo and Maisaroh (in Bhinadi. A, 2017: 26) states that empowering productive and creative local economic potential is a basic model of empowerment policy that can be done in the short term. But if the results are developed in a sustainable manner the impact will be broader in the long term and beneficial for poverty alleviation, and unemployment. This means that community empowerment must be carried out in a sustainable manner to provide long-term impacts. The utilization of existing resources is also part of the steps in community empowerment. According to Baiquni (in Bhinadi. A, 2017: 26) states, the basic concept of resource use as a step to improve the welfare of the population in rural areas. Where to realize the welfare of rural populations by utilizing rural resources concerning 3 (three) pillars, namely: (1) sustainable rural resource management in supporting the lives of rural residents; (2) the use of rural resources to strengthen the socio-economic conditions of rural people through empowering rural communities and related institutions; and (3) understanding of problems and rural resource potential. Thus empowering rural communities is an effort to alleviate poverty in rural areas.

b. Featured Village Products

The superior tourism product innovation based on the cultural diversity of an area will certainly be able to become one of the tourist attractions in the area. The concept of innovation involves the younger generation, especially in preserving the existing culture (I Putu Astawa, 2017). The innovation applied to the village's superior products will have an impact on improving the quality of the product itself. According to Ratmono, et al. 
(2016) stated that there are 3 (three) principles in the development of poultry commodities or products, namely: (1) commodities are managed with a local resource base but are globally competitive, (2) innovative and continuous creativity, (3) prioritizing the human resources development process. The sustainability of the development program and process oriented to improve product quality will have an impact on improving the quality of all resources. The village's flagship product is one of the things that can trigger economic activity. Economic growth created by rural economic activities will have a significant impact on the level of community welfare. According to Sukirno (in Eli. K, 2012), There are several factors that influence economic growth, including the following:

1. Land and other natural wealth;

2. Amount and quality of population;

3. Social systems and attitudes of the community; and

4. A market area as an economic base.

Of the four factors that can directly affect the rate of economic growth of the village community, namely land and other natural wealth. Because natural wealth will make it easier for businesses to develop the economy of a country, especially in the early periods of the process of economic growth. In addition, the majority of the population in rural areas is mostly dominated by farm laborers and farmers. So that superior village products are part of a series of populist economic development in rural areas and this aims to improve living standards or improve community welfare. In addition, innovation must be an answer to improve the quality and quantity of the village's superior products produced. The participation of the community and stakeholders is key in further developing the village's superior products.

\section{c. Quick Response Code}

QR stands for Quick Response or fast response, as the name implies, the QR-Code can convey information quickly and get a fast response from a scanner. (Mostafa, 2015) can be both horizontally and vertically, therefore information that can be accommodated is far more than barcodes (Akhmad Qashlim and Hasruddin, 2015) This code is widely used for events or organizing an event. According to Ferdinand. A.L. Et al. (2016) state that the QR-dimensional image that represents data, especially data in the form of text. With the use of this QR-Code, present information companies related to events, products, services, and information about events that will be held next digitally. Thus the QR-Code is very useful for marking a product.A quality paradigm of products, namely products that are designed as attractive as possible and there are guarantees regarding information disclosure regarding these products. The digital age has made it easy to store data in the form of QR-Code. Data storage that can only be stored in the form of word editor in each product package, can now be stored in the form of two-dimensional images in the form of QR-Code.

\section{d. Facebook Marketplace}

The development of social media in Indonesia is classified as increasing along with the number of smartphone users. In Indonesia, there are 63 million internet users and 95\% are internet users who access social media networks. Social media has become a tool for 
interaction, but also many have used it for media promotion and for the media to trade only a few use it. The data on the number of social media users in Indonesia on each platform is as follows:

Table 2.1 Number of Social Media Users in Indonesia

\begin{tabular}{lll}
\hline No. & Social Media Name & \multicolumn{1}{c}{$\begin{array}{c}\text { Number of Users } \\
\text { (million) }\end{array}$} \\
\hline 1. & Facebook & 65 \\
2. & Twitter & 19.5 \\
3. & Line & 10 \\
4. & Google & 3.4 \\
5. & Path & 700 \\
\hline & Source: Kominfo, 2013.
\end{tabular}

From the data obtained, Facebook topped the number of users for the platform or application. In addition to being used to socialize, social media is now widely used as a means of product promotion. One very interesting feature on the Facebook application that has undergone a renewal, namely Facebook Marketplace. Facebook Marketplace is a new service offered by Facebook Business, where we can sell goods or products displayed on the page. With the existence of these services, can encourage sales for each product displayed. So that the use of social media is not only a means of communicating and socializing between individuals with one another but can encourage the improvement of the community's economy. To display products that want to be sold or promoted, users only upload photos or images that will be displayed on the Marketplace Facebook page. The marketplace was created because of the many buying and selling activities in the social network. Buying and selling activities start on Facebook Groups and until now there are more than 450 million people who do it every month (Kompas, 2016). The display for Marketplace is available on the mobile application.

When opening the Marketplace, users will be welcomed with a series of photos of the merchandise. This will make it easier for users to find items and sell items in a Marketplace forum that has been provided by Facebook. In relation to the marketing strategy of a product, the use of the platform is very adaptive with the progress of the times. So that the platform is very useful for economic progress and good promotional media in today's digital era. But in terms of the use of the application must also pay attention to the elements of graphic design for attractiveness to buyers. According to Christin. M (2018) states, as for the basic principles of graphic design, as follows:

a. Balance, as sharing the burden evenly;

b. Rhythm, which is a pattern created through repetition of varied elements;

c. Accentuation, as an emphasis on what is desired to be seen first by the audience; and

d. Unity, which is when all elements appear to be related to one another.

Based on this, the use of social media for promotional facilities must prioritize designs that are suitable for the products sold. The proficiency of users in utilizing these technologies is very necessary, in order to maximize the potential that exists in the application. 
Page 510-519 ISBN: 978-602-6 988-75-1

Web Jurnal Online: jurnal.unmuhjember.ac.id

By: Irfan Nursetiawan; Kiki Endah, Ii Sujai

Digitalization Of Superior Products Sukamaju Village Cihaurbeuti Sub-District Ciamis District Based On Qr Code And Facebook Marketplace

\section{Framework}

Based on the description above, then the framework of thought in this service proposal, namely: (a) empowerment of rural communities is an effort to alleviate poverty in rural areas; (b) superior village products are part of a series of populist economic development in rural areas and this aims to improve living standards or improve community welfare; (c) QR-Code is a two-dimensional image that represents a data, especially data in the form of text; dam (d) Facebook Marketplace is a place created for buying and selling activities in the social network.

\section{Method}

The process model used as a method in community service is the Waterfall Model. The following is an explanation of the Waterfall Model stages:

a. Communication at this stage, identification of problems that occur in superior village products is carried out, and questionnaires are also distributed to obtain data on the needs of prospective product buyers.

b. Planning At this stage, the purpose and scope of service are determined so that service can be carried out more directed.

c. Modeling At this stage, a literature study and search for reference sources that support the theoretical basis of service are carried out, analysis of the current system while reviewing the weaknesses and strengths of the system, determining the problem-solving proposal based on the results of the questionnaire and identifying information will be displayed on the application, as well as performing the application system design and initial design of the user interface.

d. Construction at this stage, application programming is carried out based on the system design that has been made at a later stage.

e. Deployment at this stage, testing of integrated applications in accordance with the design has been carried out, evaluation based on user interface and user acceptance test, and making conclusions and suggestions so that applications can be better developed.application.

So that the method used in the implementation of Community Service is as follows:

a. Data collection

Data collection is carried out, namely towards community groups engaged in MSMEs and productive communities that have collaborated with BUMDes.

b. Socialization and Education

Dissemination and education are carried out on the importance of the use of information technology, especially with regard to the QR Code that functions as a digital identity and Facebook Marketplace as a media campaign and selling in the millennial era.

c. Making QR Code and Facebook Marketplace account

Making a QR Code is done through the website https://www.the-qrcodegenerator.com/ and for the Facebook Marketplace account using the Facebook account of BUMDes. 
d. Training in making QR Code and optimizing Facebook Marketplace

This training is oriented to the level of proficiency of the target audience in making the QR Code and Facebook Marketplace online.

\section{RESULT}

\section{a. Motivate the Target Audience}

After data collection and socialization of Community Service on Digitization of Featured Products in Sukamaju Village, Cihaurbeuti Subdistrict, Ciamis District based on QR Code and Facebook Marketplace, there was an increase in the motivation of the Sukamaju Village in Cihaurbeuti Subdistrict, which was only $10 \%$ to $90 \%$. This can be seen from the enthusiasm of the participants in the event. In addition, the event was attended by the Head of Sukamaju Village, Sukamaju Village apparatus, directors and members of the Village Owned Enterprises (BUMDes), chairman and members of the Family Empowerment Post (Posdaya), youth and community leaders, and activists of Micro, Small and Medium Enterprises (MSMEs) ) in the Sukamaju Village District, Cihaurbeuri District, Ciamis Regency.

In addition, the community is aware that productive activities through entrepreneurship can improve the welfare of rural communities who still uphold local wisdom and culture. The populist economy and labor-intensive practices that are still maintained in the culture of the village community make the economy of the village community run well. In addition, the community is very interested in the implementation of the use of information technology for the economic activities of rural communities and this has become a new thing in an effort to improve the marketing of superior products of the village.

\section{b. Digitizing the Village's Leading Products}

The superior products in Sukamaju Village under the guidance and development of BUMDes include robusta coffee, green tea, shredded chili, and sugar and honey. All of these products are the superior products of Sukamaju Village and have been packaged with simple packaging. After the Community Service (PKM) activity was held on February 18, 2019, in the Hall of Sukamaju Village, the BUMDes will include the QR Code as a form of digitizing the superior products of the village. The QR Code that is made includes the origin of the product, Contact Person and dynamic QR Code that lists the link or Uniform Resource Locator (URL) from the official account of the product's social media.

\section{c. Optimization of QR Code and Facebook Marketplace}

The form of optimizing the QR Code and Facebook Marketplace, namely by making a QR Code online on a website that is not paid and this is an innovation to introduce local or village products to the public digitally. This is also the first step for BUMDes to optimize from the use of information technology, especially those provided by the Facebook platform, Facebook Marketplace. Facebook Marketplace is one of the features of Facebook that functions for Facebook account users to sell online and can also 
Proceeding ICOGISS 2019

Page 510-519 ISBN: 978-602-6 988-75-1

Web Jurnal Online: jurnal.unmuhjember.ac.id

By: Irfan Nursetiawan; Kiki Endah, Ii Sujai

Digitalization Of Superior Products Sukamaju Village Cihaurbeuti Sub-District Ciamis

District Based On Qr Code And Facebook Marketplace

be an effective promotional media to bring in customers. The form of a display from Facebook Marketplace is as follows:

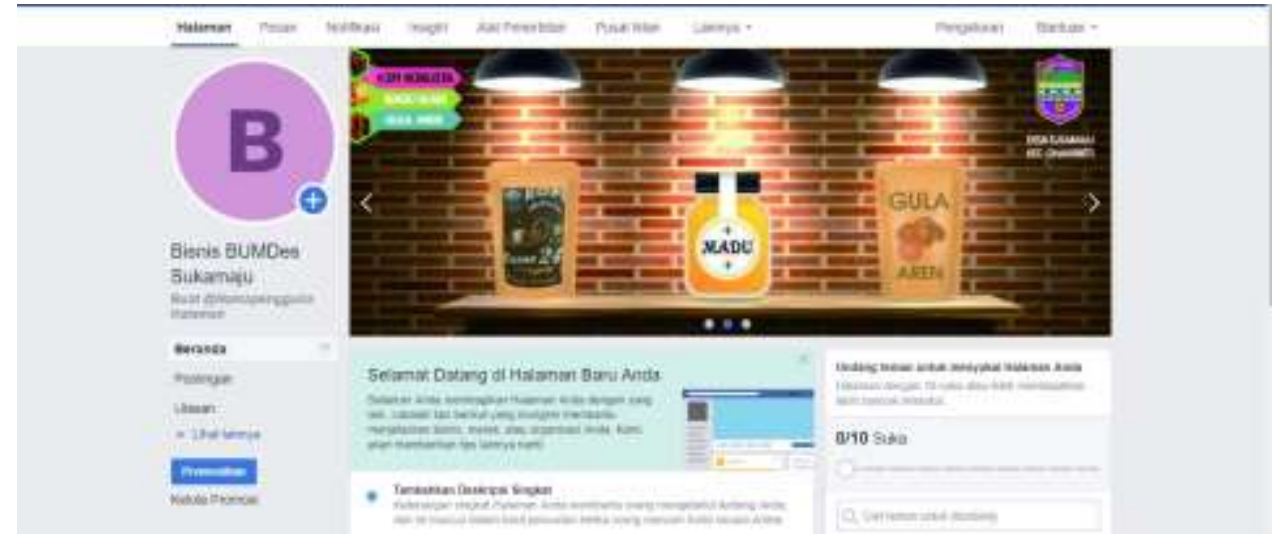

Figure 1 Facebook Marketplace of the Sukamaju BUMDes Source: Private Documentation, 2019.

Based on the Facebook Marketplace display of BUMDes Sukamaju, it is oriented towards the promotion of local products, which of course still elevates the values of local wisdom. Products displayed on the Marketplace Facebook include packaging coffee, packaged tea, and sugar or sugar palm, and packaged forest honey. After guidance and guidance was given to directors and members of BUMDes, as well as the community in Sukamaju Village, Cihaurbeuti Subdistrict, the Facebook Marketplace could be used as a media for promotion, publication, and media to sell through social media. The reach of prospective buyers and customers can be easily done. In addition, with the QR Code listed on the packaging of each product, both buyers and sellers can find out about the identity of the product. But there is a slight problem when implementing the QR Code and Facebook Marketplace, that is not all Human Resources (HR) in Sukamaju Village are proficient in using social media and understanding in implementing information technology utilization.

\section{CONCLUSION}

Based on the results of the discussion, conclusions can be obtained from the results of Community Service, as follows:

a. The motivation of the community to become entrepreneurs and utilize information technology increases after the PKM activities are carried out.

b. The QR Code can be used as a media for promotion and the identity of a product stored in a two-dimensional image placed on the product packaging.

c. Facebook Marketplace can help groups of Micro, Small and Medium Enterprises (MSMEs) and Village-Owned Enterprises (BUMDes) in marketing social mediabased products.

d. QR Code and Facebook Marketplace is a digital platform that can be used by the general public, especially rural communities, but needs to be modified and optimized that supports the marketing of superior village products. 
Page 510-519 ISBN: 978-602-6 988-75-1

Web Jurnal Online: jurnal.unmuhjember.ac.id

By: Irfan Nursetiawan; Kiki Endah, Ii Sujai

Digitalization Of Superior Products Sukamaju Village Cihaurbeuti Sub-District Ciamis

District Based On Qr Code And Facebook Marketplace

\section{REFERENCES}

Akhmad Qashlim dan Hasruddin. 2015. Implementasi Teknologi QR-Code untuk Kartu Identitas. Jurnal Ilmu Komputer.1.(2).1-6.

Bhinadi. A. 2017. Penanggulangan Kemiskinan dan Pemberdayaan Masyarakat (Studi Kasus Daerah Istimewa Yogyakarta). Yogyakarta: CV. Budi Utama.

Christin. M .2018. Pengembangan Desain Produk Unggul IKM di Kabupaten Malang Jawa Timur yang Berdaya Saing Tinggi. Institut Teknologi Adhi Tama: Surabaya.

Eli. K. 2012. Analisis Location Quotient dalam Penentuan Produk Unggulan pada Beberapa Sektor di Kabupaten Lingga Kepulauan Riau. Jurnal Integrasi.4.(1).3146.

Ferdinand. A.L. Dkk. 2016. Aplikasi Penyedia Informasi Produk dan Penanda Stan pada Pameran Menggunakan QR Code Berbasis Android. Jurnal Teknik dan Ilmu Komputer.5.(17).91-108.

Holly. P. 2013. Social Media as a Marketing Tool: A Literature Review. University of Rhode Island.Major Papers by Master of Science Students.1-26.

I Putu Astawa. 2017. Pemberdayaan Desa Wisata Pinge Melalui Produk Unggulan Pariwisata Politeknik Negeri Bali. PNB: Bali.

Kominfo. 2013. Kominfo: Pengguna Internet di Indonesia 53 Juta Orang. (Online). Tersedia: https://kominfo.go.id [08 Desember 2018].

Kompas. 2016. Facebook Rilis Marketplace untuk Jual Beli Online. (Online) Tersedia: https://tekno.kompas.com [08 Desember 2018].

Novan, A.M., dkk. 2016. Implementasi Quick Response (QR) Code pada Aplikasi Validasi Dokumen Menggunakan Perancangan Unified Modelling Language (UML). Jurnal Antivirus.10.(1).42-50.

Peraturan Pemerintah Nomor 43 tahun 2014 tentang Peraturan Pelaksanaan Undangundang Nomor 6 tahun 2014 tentang Desa.

Undang-undang Nomor 6 tahun 2014 tentang Desa. 